\title{
SUBLETHAL EFFFCTS OF COPPER SULFATE, MALATHION AND PARAQUAT ON PROTEIN PATTERN OF OREOCHROMIS NILOTICUS
}

\author{
Khalid Sharaf-Eldeen and Nassr-Allah Abdel-Hamid \\ Zoology Department, Faculty of Science, Zagazig University, Banha \\ Branch
}

Keywords: electrophoresis, serum protein, copper, malathion, paraquat, Oreochromis niloticus.

\section{ABSTRACT}

The present study deals with the effect of some water pollutants; 1 copper sulfate as a fungicide, malathion as an insecticide and paraquat as a herbicide, on srum total protein, serum albumin and globulin. Furthermore, protr:inogram of blood serum niloticus in Oreochromis was done using electrophoresis. It was found that the control fish have nine serum protein fractions. The exposure of fish to the examined pollutants induced a disappearance of some fractions and consequently changes of relative mobility and area that indicate genetic damage.

\section{INTRODUCTION}

Nowadays, with the extensive use of pesticides and herbicides, some of these compounds have been drained either directly or indirectly to the aquatic environment. In such way, the chemical composition of the water ecosystem was changed. Thus, pollution of such habitat has been generated. The degree of poltution in any area in the River Nile depends on the quantity of wastes washed down (Siliem, 1993; 1994 and Badawy \& El-Serafy, 1998). Serum protein fractions of Clarias gariepinus were used by Badawy and El-Serafy (1998) to detect the pollution level of the aquatic habitat. Therefore, the present study aims to investigate laboratory effect of some water pollutants on protein polymorphism of Nile tilapia (O. niloticus). 


\section{MATERIALS \& METHODS}

Nile tilapia fishes were reared in large acquaria in the fish biology laboratory, Benha Faculty of Science, in a healthy status. The fishes selected for this study nearly measure $17-23 \mathrm{~cm}$ of both sexes. The photoperiod in the laboratory was adjusted to $14 \mathrm{~L}: 10 \mathrm{D}$. The fishes then were transferred to glass acquaria for the experimental work. One fish group was left as a control. The other acquaria were used for the pollution study. The insecticide, malathion (Kafr El-Zayat insecticide Co., Egypt) and the herbicide, paraquat (methyl viologen) (Sigma) were added separately at levels of 0.1, $0.01,0.001$ and $0.0001 \mathrm{mg} / \mathrm{L}$ each in separate tanks. Copper sulfate, anhydrous (Spectrum quality products Inc., USA) was added at levels of $1.0,0.5,0.1$ and $0.01 \mathrm{mg} / \mathrm{L}$ in separate tanks. Ten fishes were raised in each tank. The fishes were fed twice a day with a standard fish food. The levels of the pollutants were approximately kept constant throughout the experiment. The experiment continued for four days. The fishes of the control and polluted exposed groups were decapitated by heart puncture and the blood samples were collected into non-heparinized tubes. The tubes were left overnight at $4^{\circ} \mathrm{C}$ to complete the clotting. The blood samples were centrifuged at 4000 rpm for $5 \mathrm{~min}$ and serum samples were separated and stored in deep freeze until analysis.

The serum total protein was determined following the Biuret principle, using Biomereux kit (Sentinel diagnostic kit cat No $17261 \mathrm{~A}$ ). The serum globulin level was calculated by substracting the albumin from total protein levels.

Protein fractionation was done using SDS polyacrylamide gel electrophoresis (SDS-PAGE) (Herzberg \& Pasteur, 1975). The gels were stained in Comassie Brilliant Blue and the excess dye was washed using destaining solution (methanol \& acetic acid). The gel bands were scanned using densitometer and the date analysed using Hoefer 365 software (Heofer Scientific Instruments, CA. USA). The t-student test was used as a test of significance between the control and treated groups (Pipkin, 1984).

\section{RESULTS}

The data presented in table (i) shows the changes of serum total protein, albumin and globulin levels of the control as well as the fishes subjected to the pollutants. Evidently, the serum total protein 
was generally increased in case of the fishes subjected to the examined pollutant. All malathion concentrations induced a significant increase of protein level. The serum of fishes exposed to $0.0001 \mathrm{mg}$ malathion $/ \mathrm{L}$ showed the highest elevation $(6.33 \%)$ of serum total protein.

The serum albumin was significantly reduced in case of fish reared in malathion and $\mathrm{CuSO}_{4}$ polluted water, whereas paraquat induced a significant elevation of albumin level that was evident at the lowest concentration $0.0001 \mathrm{mg} / \mathrm{L}$.

A general increase of globulin level was recorded in the blood of tilapia fish reared in water polluted with malathion and $\mathrm{CuSO}_{4}$ (Table 1). The highest value $(1.71 \pm 0.14 \mathrm{mg} / 100 \mathrm{ml})$ was recorded in case of $0.01 \mathrm{mg} / \mathrm{L}$ malathion subjected fishes. This value differed from the control by $25 \%$ percentage difference. The paraquat at a dose level of $0.01 \mathrm{mg} / \mathrm{L}$ induced a significant rise of globulin level with a percentage difference $17.65 \%$, when compared with the control group, whereas the lowest tested levels of this insecticide $(0.0001 \mathrm{mg} / \mathrm{L})$ induce a marked reduction of the circulating globulin.

The electrophoretic serum protein fractionations of $O$. niloticus reared in non-polluted water displayed 9 fractions (Table 2; Fig.1). By the exposure of fishes to the highest tested copper level $(1.0 \mathrm{mg} / \mathrm{L})$, the protein pattern showed three fractions only (i.e six fractions were missing)(Table $2 \&$ Fig.2). The rest of the examined copper levels showed no effect. One fraction only was missing as a result of $0.1,0.01$ and $0.001 \mathrm{mg} / \mathrm{L}$ malathion exposure (Table $2 \&$ Fig.3). However, the lowest tested malathion level $(0.0001 \mathrm{mg} / \mathrm{L})$ showed more or less the same pattern as control. In treatment with all paraquat concentrations two fractions were missing (Table 2 \& Fig.4). Fractions number 2, 3 and 1,2 were missing in case of paraquat exposure levels $0.1,0.01$ and $0.001,0.0001 \mathrm{mg} / \mathrm{L}$, respectively.

The percentage of frequency appearance of various serum protein fractions of $O$. niloticus in different groups is presented in table (2). This study was confined mainly on the polymorphic fractions. The polymorphism (appearance $>50 \%$ ) of protein fractions of control group was noted for all fractions except fraction number 1 . This phenomenon was also noted for all exposed groups.

Table (3) shows the relative mobility of protein fractions which indicates the relative genetic distance in which fraction 
migrates from the application sample's point to its position in the electropherogram through the gel. Fractions number 1, showed a significant mobility in all fish groups reared in copper polluted water. The lowest $\mathrm{Cu}$ concentration induced a significant mobility of fraction numbers 2,4 and 5 . Fraction number 1 showed a significant reduction of relative mobility after exposure to $1.0 \mathrm{mg} / \mathrm{L} \mathrm{Cu}$.

The relative mobility of protein fraction number 1 was significantly different from the control value. This was reported in case of malathion concentrations 0.01 and $0.001 \mathrm{mg} / \mathrm{L}$ and $0.1 \mathrm{mg}$ paraquat /L subjected groups (Table, 3). Fractions number 2, 4, 5 and 8 showed a significant increase in mobility after exposure to concentrations $0.001,0.01$ and $0.1 \mathrm{mg}$ malathion $/ \mathrm{L}$. The malathion exposure levels of 0.1 and $0.01 \mathrm{mg} / \mathrm{L}$ induced a marked significant increase in mobility of fraction number 7 . No significant changes in fish exposed to $0.0001 \mathrm{mg}$ malathion $/ \mathrm{L}$.

Paraquat exposure levels $(0.1$ and $0.01 \mathrm{mg} / \mathrm{L})$ induced a significant difference of relative mobility of fractions number $1,4,5$ and 9 . Fractions number 4 and 5 showed a significant reduction in mobility as a result of exposure to 0.001 and $0.0001 \mathrm{mg}$ paraquat $/ \mathrm{L}$, whereas, fraction number 4 was significantly increased over the control levels at the lowest two paraquat levels $(0.001$ and 0.0001 $\mathrm{mg} / \mathrm{L}$ ).

The relative areas of all protein fractions were significantly changed after the exposure of fish to the highest copper concentration $(1.0 \mathrm{mg} / \mathrm{L})$ (Table 4). Fractions number 1, 2, 3 and 6 showed a higher relative area after all tested copper levels. Conversely, the bands number 4, 5, 7 and 9 showed a reduced area (Table 4). The malathion and paraquat concentrations induced a marked increase of relative area of bands number $5,6,7,8$ and 9 showed a reduced value.

\section{DISCUSSION}

The studies on protein metabolism were found to be of a vulnerable value of fish population. The structure of blood proteins, muscle proteins, haemoglobins as well as enzymes in the blood and some organs appear to be variable (Boyd, 1964 and Kirpichinkov, $1973 \&$ 1981). The determination of protein content in the blood plasma is a good indicator for the ecological stress, physiological homeostasis and aquatic pollution (Abdel-Hamid, 1994). The results obtained in the present investigation showed an elevated serum protein content after the exposure to the tested pollutants. This 
phenomenon reflects the hazardous effect due to such pollutants (Abdel-Hamid, 1994 and Sharafeldeen, 1999). Moreover, Sharafeldeen (1999) reported that the histological investigation of $O$. niloticus subjected to sublethal concentrations of $\mathrm{CuSO}_{4}$, malathion and paraquat showed expanding hepatic sinusoids, necrosis and vacuolation of hepatocytes. So, as a result of increasing hepatocellular damage, the total serum protein content was elevated. This observation was previously reported by Poleksic and Karan (1995).

The pollution of aquatic habitat by ametryn (herbicide) caused a reduction of the plasma total protein content in the grass carp (Ctenopharyngodon idella) (Abo-Hegab et al., 1990). Also, the molluscicide and uea exhibit a similar pattern of effect. This phenomenon gets the support from Patterson (1976) who reported that the pollutants react with the cell nucleoproteins and nucleic acids and consequent'y affect proteir synthesis and cell integrity.

The albumin level siowed a general reduced level in all treated groups. This may reflect a reduced blood viscosity. This phenomenon runs parallel with those obtained by Ramalingam (1982) and Awasthi el al. (1984).

Sanders (1964) found inter and intraspecific differences in protein compounds. Many authors studied the protein polymorphism which is mainly due to genetic disturbances of pollution (Payne et al., 1971; Badawy and El-Serafy, 1998 and Salama, 2001).

The present investigation found that six protein fractions were missing due to copper exposure (high level, $1.0 \mathrm{mg} / \mathrm{L}$ ). This result revealed a high genetic damage that was occurred due to copper. This phenomenon was previously reported by Badawy and El-Serafy (1998) and Salama (2001). Avtalion \& Wojdani (1971) reported that, in the serum proteinogram of some tilapia, some fractions are confined to transferrin (B-globulin) which is an important genetic area. Also, Bus et al. (1977) described that paraquat induced a damage of membranes, protein and DNA.

Khud-Bukhsh et al. (1987) mentioned that polyacrylamide gel electrophoretic bands of glutamine, albumin globulin and muscle protein of X-radiated tilapia differed significantly with respect to number, mobility and density of bands than that of the control.

The significance in the relative areas of protein fractions reported in the present study as a result of pollution is mainly due to 
the polyorphism and disappearance of some fractions. This explanation was suggested previously by many authors (El-Sharkawi et al., 1978; Siliem, 1994; Yacoup, 1994 \& Awad and El-Serafy 1998).

The protein electrophoresis revealed a high difference between control and polluted samples due to the production or activation of a new sequence of DNA responsible for synthesizing new types of protein as concluded by El-Bermawy et al. (2000)

The present study indicates that the examined pollutants; copper sulfate, malathion and paraquat induce a rise of circulating protein content, protein polymorphism and inhibition of some fractions which reflects a genetic damage due to the pollutants.

\section{REFERENCES}

Abdej-Hamid, N. A. H. (1994). Effect of some pollutants on biological aspects of Oreochromis niloticus. M. Sc. Thesis, Faculty of Science, Zagazig Univ., Benha Branch, pp198.

Abo-Hegab, S. ; Marie, M. A. and Kandil (1990). Changes in the plasma lipid and total protein of grass carp (Ctenopharyngodon idella) during environmental pollutant toxicity. Bull. Zool. Soc. Egypt, 39: 211-222.

Avtalion, R. R. and Wojdani, A. (1971). Electrophoresis and Immuno-electrophoresis on sera from some known $F 1$ hybrids of Tilapia. Bamidgeh, 23: 177-124.

Awasthi, M. ; Shah, P. ; Dubale, M. S. and Gohia, P. (1984). Metabolic changes induced by organophosphorus in piscine organs. Environ. Res., 35: 320-325.

Badawy, E. A. and El-Serafy, S. S. (1998). comparative biochemical genetic studies on Claris gariepinus from different polluted localities. Menofiya J. Agric. Res., 23(6):1705-1715.

Boyd, D. W. (1994). Modern ideas on race in the light our knowledge of blood groups and other characters with known mode of inheritance. In: Taxonomic Biological Serology (A. Leone, ed.), $728 \mathrm{pp}$. 
Bus, T. S. ; Aust, S. D. and Gibson, J. E. (1977). In "Biochemical mechanisms of paraquat toxicity", ed. By A. P. Autors Academic Press New York, pp. 157-172.

El-Bermawy, S. M. (2000). Changes in total protein in larvae of Corcyra cephalonica due to irradiation and heat stress. Arab J, of Nuclear Sciences and Application.

El-Serafy, S. S. and Badaway, E. A. (1998). The effect of pollution on the muscle proteinograms of Claris lazera from different areas. Menofia J. Agric. Res. 23(6):1717-1727.

El-Sharkawi, F. M. ; Samaan, A. A. ; Ezzat, A. ; Sebae, S. ; Saad, S. and Hamza, A. (1978). Pollution of the water lake Mariut and its sources. (In Arabic) Report Published by the hig! Instivite of Public health.

Herzberg, B. and Pasteur, $K$. (1975). The identification of the gray Mullet species by disc electrophoresis. Aquacult., 5: 99106.

Kirpichinkov, V. S. (1873). Biochemical polymorphism and micrevolution in fish. In: "Genetics and Mutagenesis of Fish", (J. H. Schroder ed.), Spring-Verlag, Berlin, pp. 223241.

Kirpichinkov, R. S. (1981). The genetic basis of fish selection. Springer, Berlin-Heidlberg, New York.

Patterson, D. S. P. (1976). Structure metabolism and toxicity of aflatoxin Cab. Nutr. Diet (suppl.2) 71-78.

Payne, H. ; Child, A. R. and Forrest, A. (1971). Geographical variation in the Atlantic salmon. Nature, 231: 250-252.

Pipkin (1984). Medical statistics made easy. Chuechill Livingstone Edinberg, London, Melbourn and New York. 
Poleksic, V. and Karan, V. (1995). Pathological effects of some herbicides to carp. Pesticide, 10:41-47.

Ramalingam, K. (1982). Effect of sublethal levels of DDT, malathion and parathion. Indian Anim. Sci., 91: 172-179.

Salama, M. A. M. (2001). Experimental studies on the cytogenetic of a certain fresh water fish. Ph. D. thesis, Zagazig Univ., Fac. Sci., $162 \mathrm{pp}$.

Sanders, B. G. (1964). Electrophoretic studies of serum proteins of three trout species and the resulting hybrids within family salmonidae. In: Taxonomic Biochemistry and Serology (C.A. Leone, ed.), Ronald Press Company, New York.

Sharaf-Eldeen, Kh. M. (1999). Biological markers for evaluation of ecotoxicity stress and its immune effect in freshwater fish. Ph.D. Thesis, Faculty of Science, Zagazig Univ., Benha Branch, $198 \mathrm{pp}$.

Siliem, T. A. (1993). Some impacts of the chemical changes of water of the Ratama fish ponds. Menofya J. Agric. Res., 18(3): 1837-1862.

Siliem, T. A. (1994). Seasonal and diurnal variations in the physicochemical conditions of water at bifurcation of the River Nile. Menofiya. J. Agric. Res.19 (6-2): 3345-3358.

Yacoup, A. M. (1994). Effect of pollution in lake Qarun on Solea volgaris. M. Sc. College Wom. Ain Shams Univ., 205 pp. 


\section{STBLETHAL EFFECTS OF COPPER SULFATE, MALATHION AND PARAQUAT ON PROTEIN PATTERN OF OREOCHROMIS NILLOTICUS

Table 1. Changes of the serum total protein content, albumin and globulin in blood serum of control $O$. niloticus as well as those of fishes exposed to different levels or $\mathrm{CuSO}_{4}$, Malathion and Paraquat

\begin{tabular}{|c|c|c|c|c|c|c|c|}
\hline \multicolumn{2}{|c|}{ Groupr } & \multicolumn{2}{|c|}{ Total protcis $(g / 100 \mathrm{ml})$} & \multicolumn{2}{|c|}{$\begin{array}{l}\text { Albumin } \\
\text { (pnoo onl) }\end{array}$} & \multicolumn{2}{|c|}{ Globulin (R/100 $\mathrm{ml})$} \\
\hline & & Mexa土SD & $\%$ chenge & Mean \pm SD & $\%$ chang: & $\mathrm{Alean} \pm \mathrm{SD}$ & $\%$ chouge \\
\hline Control & & $3.2 \pm 0.04$ & $\square$ & $1.8 \pm 008$ & - & $3.4 \pm 004$ & - \\
\hline \multirow{4}{*}{$\begin{array}{l}\mathrm{CuSO} \\
(\mathrm{Mg} / \mathrm{L})\end{array}$} & 1.0 & $3.1 \pm 0.1$ & -1.26 & $1.9 \pm 0.2$ & 3.89 & $1.3 \pm 0.3$ & .8 .09 \\
\hline & 0.5 & $3.3 \pm 0.1^{*}$ & 5.38 & $1.7 \div 0.1^{\circ}$ & -6.11 & $1.6 \pm 0.03^{\circ}$ & 20.59 \\
\hline & 0.1 & $3.1 \pm 0.05$ & -0.63 & $1.7 \pm 0.1$ & -3.33 & 1410.1 & 4.41 \\
\hline & 0.01 & $3.1 \pm 0.2 \%$ & -1.26 & $1.8 \pm 0.1$ & -2.78 & $1.4 \pm 0.1$ & 0.73 \\
\hline \multirow{4}{*}{$\begin{array}{l}\text { Malathion } \\
(\mathrm{M} / \mathrm{L})\end{array}$} & 0.1 & $3.3 \pm 0.5 \%$ & 2.85 & $1.7 \pm 0.1 \%$ & .6 .67 & $1.6 \pm 0.1^{*}$ & 16.91 \\
\hline & 0.01 & $3.3 \pm 0.1^{\circ}$ & 4.43 & $1.6 \pm 0.01^{\circ}$ & -11.67 & $1.7 \pm 0.1$ & 25.73 \\
\hline & 0.001 & $3.2 \pm 0.03^{\circ}$ & 2.21 & $3.7=0.1$ & -5.0 & $1.6 \pm 0.1 \%$ & $19 . \overline{12}$ \\
\hline & 0.0001 & $\overline{3.4 \pm 0.09^{\circ}}$ & 6.33 & $1.7 \pm 0.1^{*}$ & -6.67 & $1.7 \pm 0.04^{\circ}$ & 22.06 \\
\hline \multirow{4}{*}{$\begin{array}{c}\text { Parmquat } \\
\text { (MgL) }\end{array}$} & D.I & $3.1 \pm 0.2$ & -2.21 & $1.9 \pm 0.04$ & 2.78 & $1.3 \pm 0.2$ & -8.69 \\
\hline & ก.01 & $3.3 \pm 0.05^{*}$ & 4.75 & $1.7=0.01$ & -3.33 & $1.6 \pm 0.1^{\circ}$ & 17.65 \\
\hline & 0.001 & $3.1 \pm 0.2$ & -1.9 & $1.7 \pm 0.1$ & -3.89 & $1.3 \pm 0.1$ & -0.73 \\
\hline & 0.0001 & $3.2 \pm 0.1$ & 0.95 & $2.3 \pm 0.1$ & 25.55 & 0.910 .1 & -31.62 \\
\hline
\end{tabular}

"Significant al $P<0.05$

Table 2. Percentage appearance of serum protein fractions of control O. miloticus as well as those of fishes exposed to different levels of CuSO, Malathion nnd Paraquat.

\begin{tabular}{|c|c|c|c|c|c|c|c|c|c|c|}
\hline \multirow{2}{*}{\multicolumn{2}{|c|}{ Grober: }} & \multicolumn{9}{|c|}{ Fmethons number } \\
\hline & & \multirow{2}{*}{$\begin{array}{c}1 \\
33.33\end{array}$} & \multirow{2}{*}{$\frac{2}{5 i j}$} & \multirow{2}{*}{$\frac{3}{833}$} & \multirow{2}{*}{$\frac{4}{100}$} & \multirow{2}{*}{$\begin{array}{c}5 \\
66.67\end{array}$} & \multirow{2}{*}{$\frac{6}{100}$} & \multirow{2}{*}{$\frac{7}{300}$} & \multirow{2}{*}{$\frac{\pi}{100}$} & \multirow{2}{*}{ क्ज } \\
\hline Contral & & & & & & & & & & \\
\hline \multirow{4}{*}{$\begin{array}{l}\text { Cuso. } \\
(\mathrm{Mg} n)\end{array}$} & 10 & 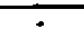 & $=$ & $\cdot$ & 100 & . & - & $\because$ & 100 & 100 \\
\hline & 0.3 & 100 & 66.67 & 100 & 66.67 & 66.67 & 100 & 100 & 100 & IING \\
\hline & 0.1 & 30 & 50 & 100 & 30 & 100 & 50 & $\sin$ & 100 & 30 \\
\hline & 0.01 & 66.67 & 100 & 66.67 & 33.13 & 66.67 & 100 & 66.67 & 100 & 66,67 \\
\hline \multirow{4}{*}{$\begin{array}{l}\text { Malathion } \\
\text { (M/2/L) }\end{array}$} & 0.1 & - & 66.67 & 150 & 66.67 & $\ln \theta$ & 100 & 100 & 100 & 66.67 \\
\hline & 0.01 & 33.31 & 100 & 1170 & - & 66.67 & 100 & 66.67 & 3.33 & 100 \\
\hline & 0.061 & 100 & 100 & 100 & . & 100 & 100 & 30 & (5) $\mathrm{w}$ & $T(x)$ \\
\hline & 0.0001 & 31.3 .3 & 100 & $10 \pi$ & 66.67 & 100 & $T(x)$ & 66.67 & 101 & $\mathrm{~F}_{3} \mathrm{Cl}_{37}$ \\
\hline \multirow{4}{*}{$\begin{array}{l}\text { f'aryqual } \\
\text { (Meft) }\end{array}$} & 0.1 & $\overline{30}$ & - & $\cdot$ & 109 & 1010 & 307 & 100 & 1001 & $\mid(x)$ \\
\hline & 0.01 & 33.3 .1 & $\cdot$ & - & 3333 & 66.67 & 33.33 & 100 & 100 & 100 \\
\hline & 0001 & $=$ & 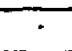 & 6.67 & 100 & ThG.67 & 66.67 & 100 & म0 & $\overline{i x j}$ \\
\hline & 0.0001 & - & - & 33.33 & 100 & 6667 & 66.67 & 100 & 100 & IIN \\
\hline
\end{tabular}




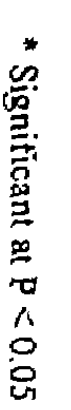

\begin{tabular}{|c|c|c|c|c|c|c|c|c|c|c|c|c|c|c|c|}
\hline & \multicolumn{3}{|c|}{ 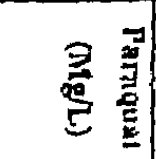 } & \multicolumn{4}{|c|}{ 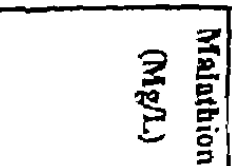 } & \multicolumn{4}{|c|}{ 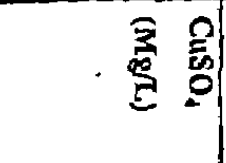 } & \multirow[t]{2}{*}{ 豙 } & & \multirow{2}{*}{$\stackrel{\Omega}{3}$} & \\
\hline 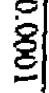 & 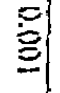 & $\stackrel{0}{=}$ & $=$ & 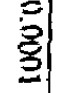 & 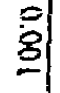 & 일 & 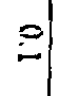 & 일 & $=$ & is & $\overline{0}$ & & & & \\
\hline 1$]$ & & $\begin{array}{l}\bar{n} \\
\vdots \\
4 \\
\vdots \\
-1\end{array}$ & $\begin{array}{l}5 \\
4 \\
4 \\
\vdots \\
\vdots \\
7\end{array}$ & $\begin{array}{l}5 \\
\infty \\
+ \\
\vdots \\
\vdots\end{array}$ & $\begin{array}{c}0 \\
a \\
+ \\
\vdots \\
\vdots \\
\vdots\end{array}$ & $\begin{array}{l}5 \\
8 \\
0 \\
0 \\
0\end{array}$ & ' & $\begin{array}{l}\overrightarrow{3} \\
\vdots \\
4 \\
0 \\
\vdots \\
4\end{array}$ & 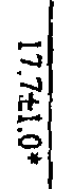 & 点 & 1 & $\begin{array}{l}5 \\
\vdots \\
\\
0\end{array}$ & $\begin{array}{l}3 \\
6 \\
= \\
4 \\
6\end{array}$ & $\sim$ & \\
\hline * & ' & & & 雚 & \begin{tabular}{c}
0 \\
0 \\
$\omega$ \\
0 \\
0 \\
\hdashline
\end{tabular} & 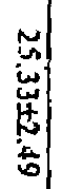 & 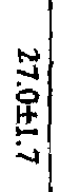 & $\begin{array}{l}0 \\
0 \\
0 \\
0 \\
0 \\
\vdots\end{array}$ & 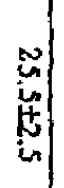 & 足 & ' & $\begin{array}{l}n \\
w \\
H \\
i \\
\text { in }\end{array}$ & 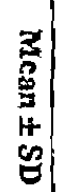 & $N$ & \\
\hline 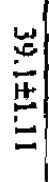 & 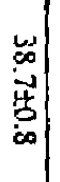 & & & 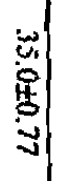 & 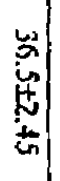 & 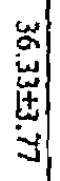 & | & 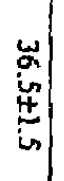 & 岕 & $\begin{array}{l}0 \\
0 \\
0 \\
0 \\
0 \\
0 \\
0\end{array}$ & ' & 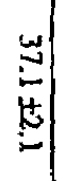 & $\begin{array}{l}3 \\
8 \\
8 \\
\dot{y} \\
0 \\
0\end{array}$ & $\omega$ & \\
\hline 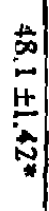 & 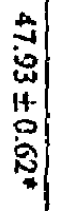 & 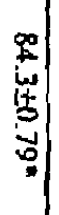 & $\begin{array}{l} \pm \\
4 \\
4 \\
5 \\
5 \\
0 \\
0\end{array}$ & 弆 & ' & 1 & 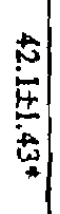 & 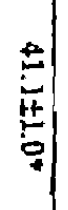 & 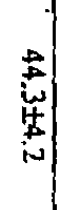 & 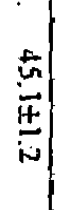 & 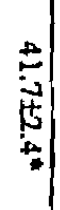 & 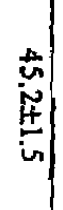 & $\begin{array}{l}3 \\
0 \\
6 \\
H \\
0 \\
0\end{array}$ & + & 31 \\
\hline 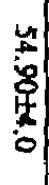 & 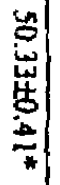 & 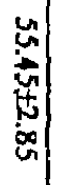 & 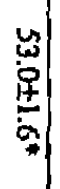 & 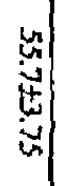 & 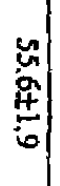 & 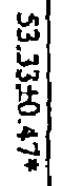 & \begin{tabular}{l}
$n$ \\
\multirow{4}{4}{} \\
in
\end{tabular} & 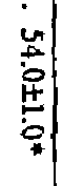 & : & 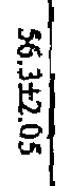 & ' & 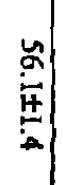 & 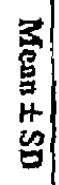 & in & 量 \\
\hline 量 & 查 & $\begin{array}{c}0 \\
0 \\
0 \\
0 \\
0 \\
0 \\
0\end{array}$ & $\begin{array}{l}g \\
\dot{u} \\
u \\
w \\
\omega\end{array}$ & $\begin{array}{l}2 \\
\vdots \\
4 \\
4 \\
\vdots \\
\vdots\end{array}$ & 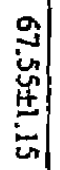 & 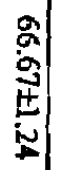 & 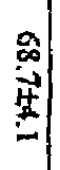 & $\begin{array}{l}a \\
2 \\
\vdots \\
\vdots \\
\vdots \\
4\end{array}$ & $\begin{array}{l}0 \\
0 \\
0 \\
0 \\
\vdots \\
\vdots\end{array}$ & 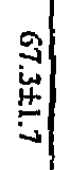 & ' & 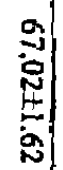 & 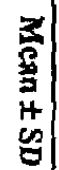 & $a$ & \\
\hline 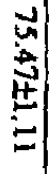 & 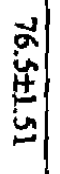 & 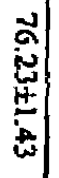 & 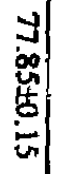 & $\begin{array}{l}7 \\
+ \\
0 \\
7 \\
= \\
=\end{array}$ & 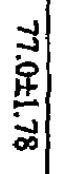 & $\begin{array}{l}-1 \\
0 \\
0 \\
5 \\
0 \\
0 \\
0\end{array}$ & $\begin{array}{c}-1 \\
0 \\
0 \\
-\end{array}$ & 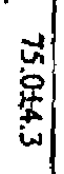 & 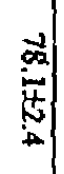 & $\begin{array}{c}d \\
\vdots \\
\vdots \\
+ \\
\vdots\end{array}$ & 1 & \begin{tabular}{l}
$n$ \\
0 \\
0 \\
\multirow{2}{*}{}
\end{tabular} & 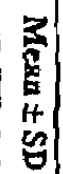 & $\rightarrow$ & \\
\hline 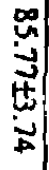 & 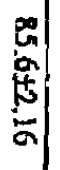 & 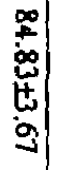 & $\begin{array}{l}\infty \\
-3 \\
0 \\
0 \\
0 \\
0\end{array}$ & 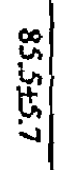 & 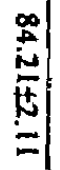 & 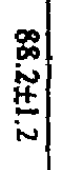 & 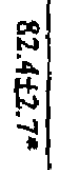 & $\begin{array}{c}0 \\
\infty \\
\vdots \\
\vdots \\
\vdots \\
0 \\
\infty \\
\vdots\end{array}$ & | & $\begin{array}{c}\infty \\
\infty \\
\vdots \\
5 \\
\vdots \\
-n\end{array}$ & $\begin{array}{c}\infty \\
\infty \\
\infty \\
0 \\
0 \\
0\end{array}$ & 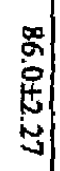 & $\begin{array}{l}3 \\
8 \\
5 \\
5 \\
9\end{array}$ & $\infty$ & \\
\hline 㞾 & 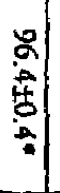 & 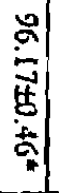 & $\begin{array}{l}0 \\
0 \\
0 \\
0\end{array}$ & 品 & 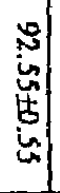 & 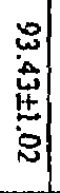 & 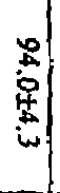 & $\begin{array}{l}0 \\
0 \\
0 \\
0 \\
0 \\
0\end{array}$ & $\frac{0}{0}$ & 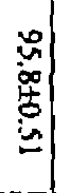 & 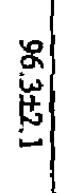 & 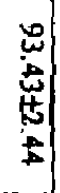 & 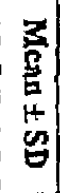 & 0 & \\
\hline
\end{tabular}

吾

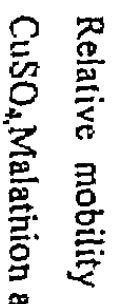

范 웅

总总

畐

氶

용

号

正

.

ำ

a

踝

兽

怘

亏ี

$\circ$

荬

疍

总

$\overrightarrow{0}$

穿 
STBLETHAL EFFECTS OF COPPER SULFATE,

MALATHION AND PARAQUAT ON PROTEIN

PATTERN OF OREOCHROMIS NILLOTICUS

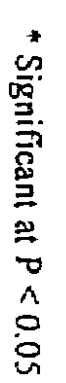

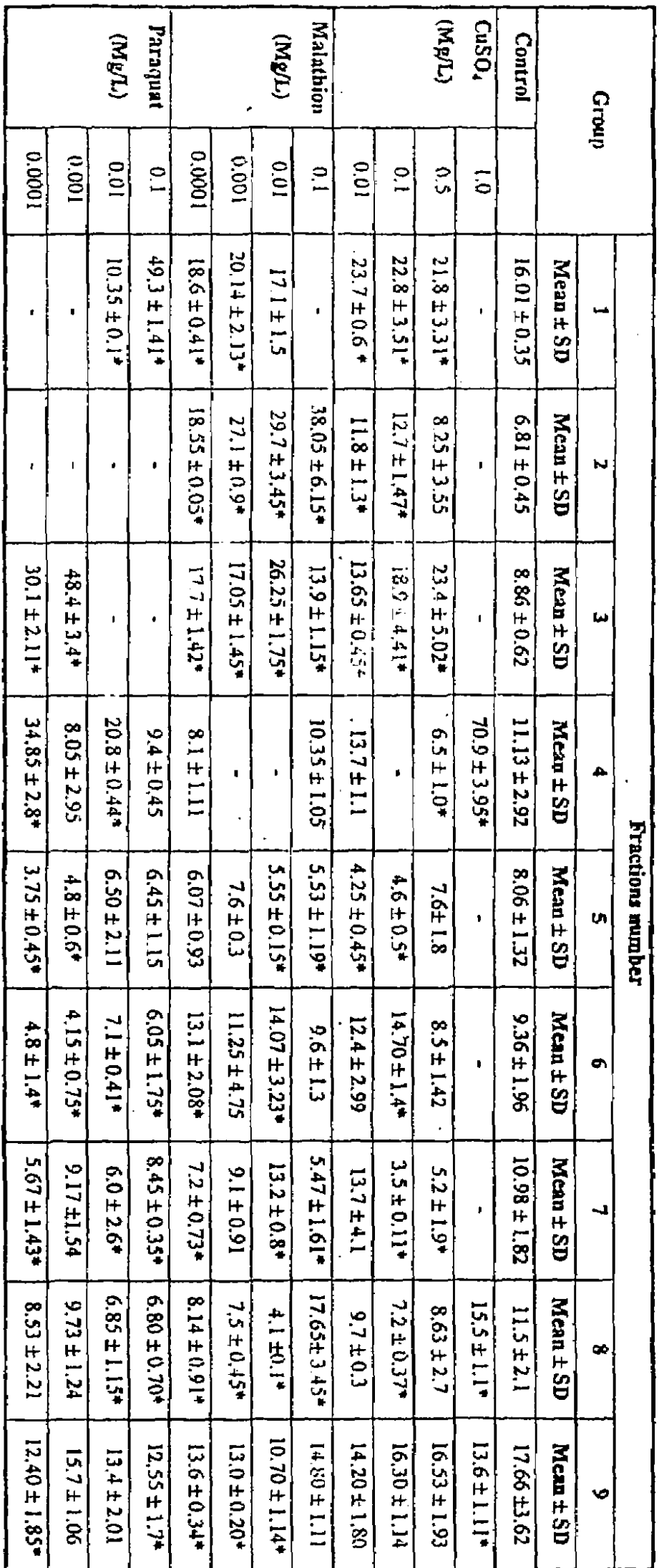

点

$\frac{7}{2}$

?ํㅛ

뭉

8

范 
$\mathrm{G} 2 \mathrm{C} 15$

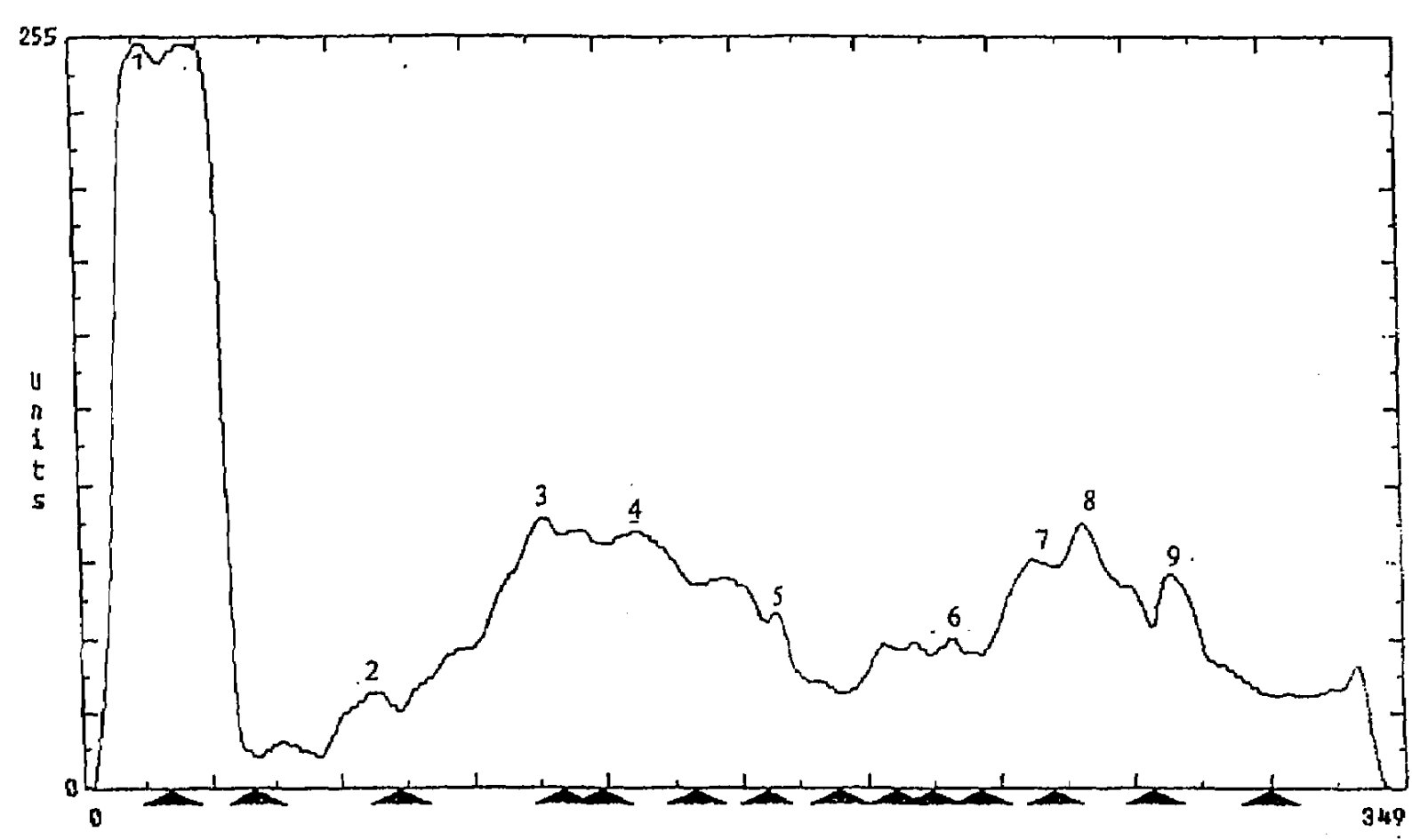

Fig. (1): Serum proteinogram of control O.niloticus. 
STBLETHAL EFFECTS OF COPPER SULFATE,
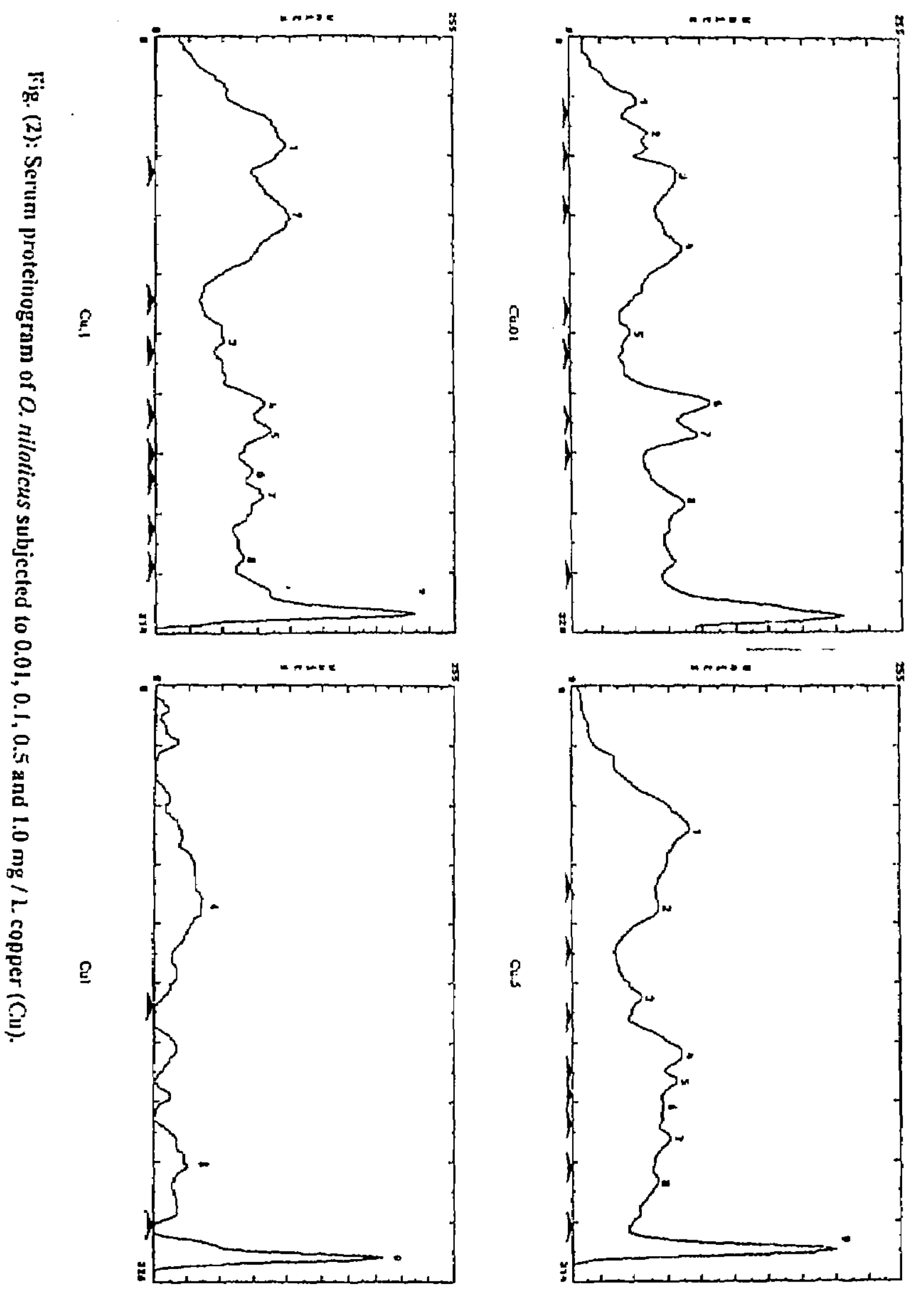

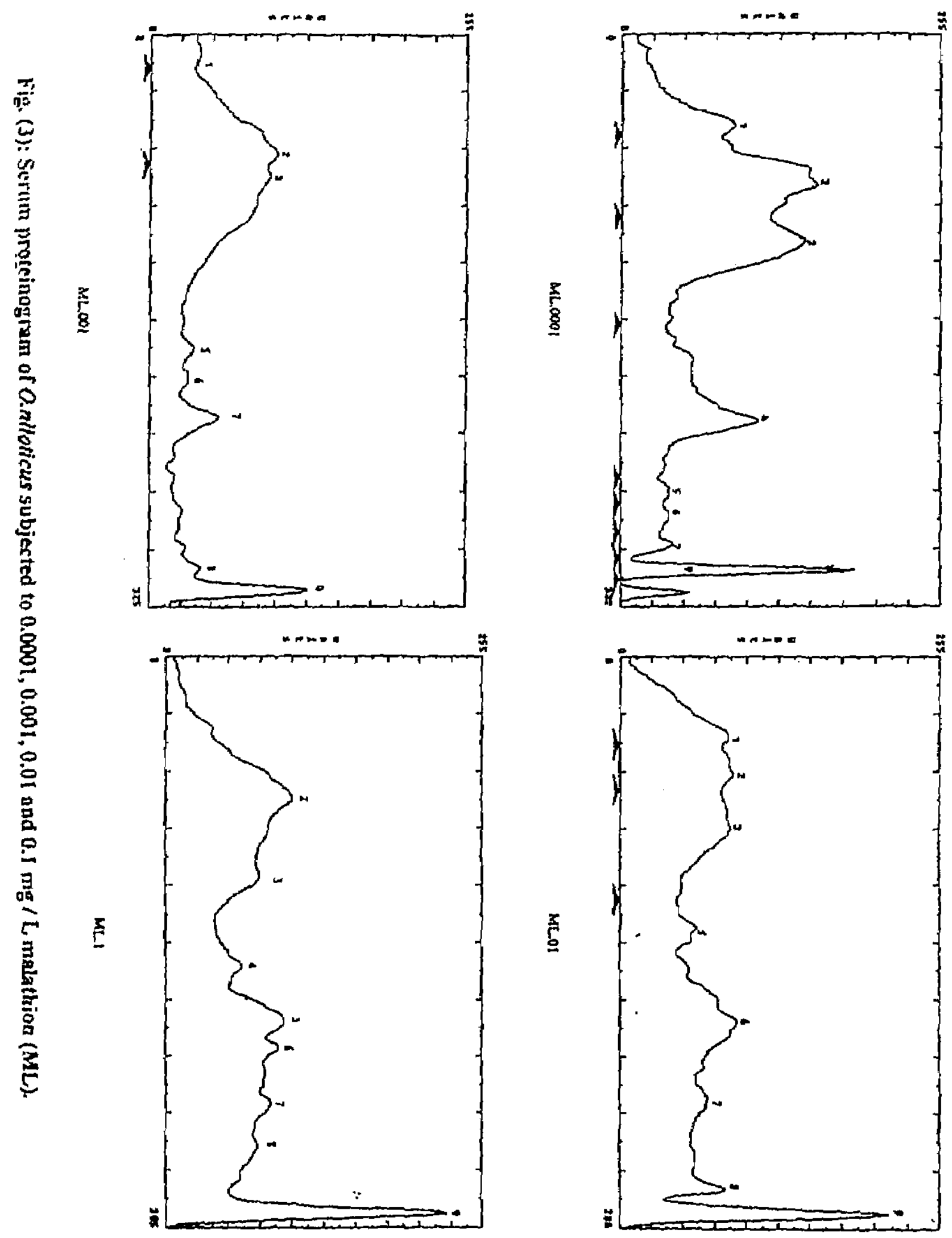
STBLETHAL EFFECTS OF COPPER SULFATE, MALATHION AND PARAQUAT ON PROTEIN PATTERN OF OREOCHROMIS NILLOTICUS
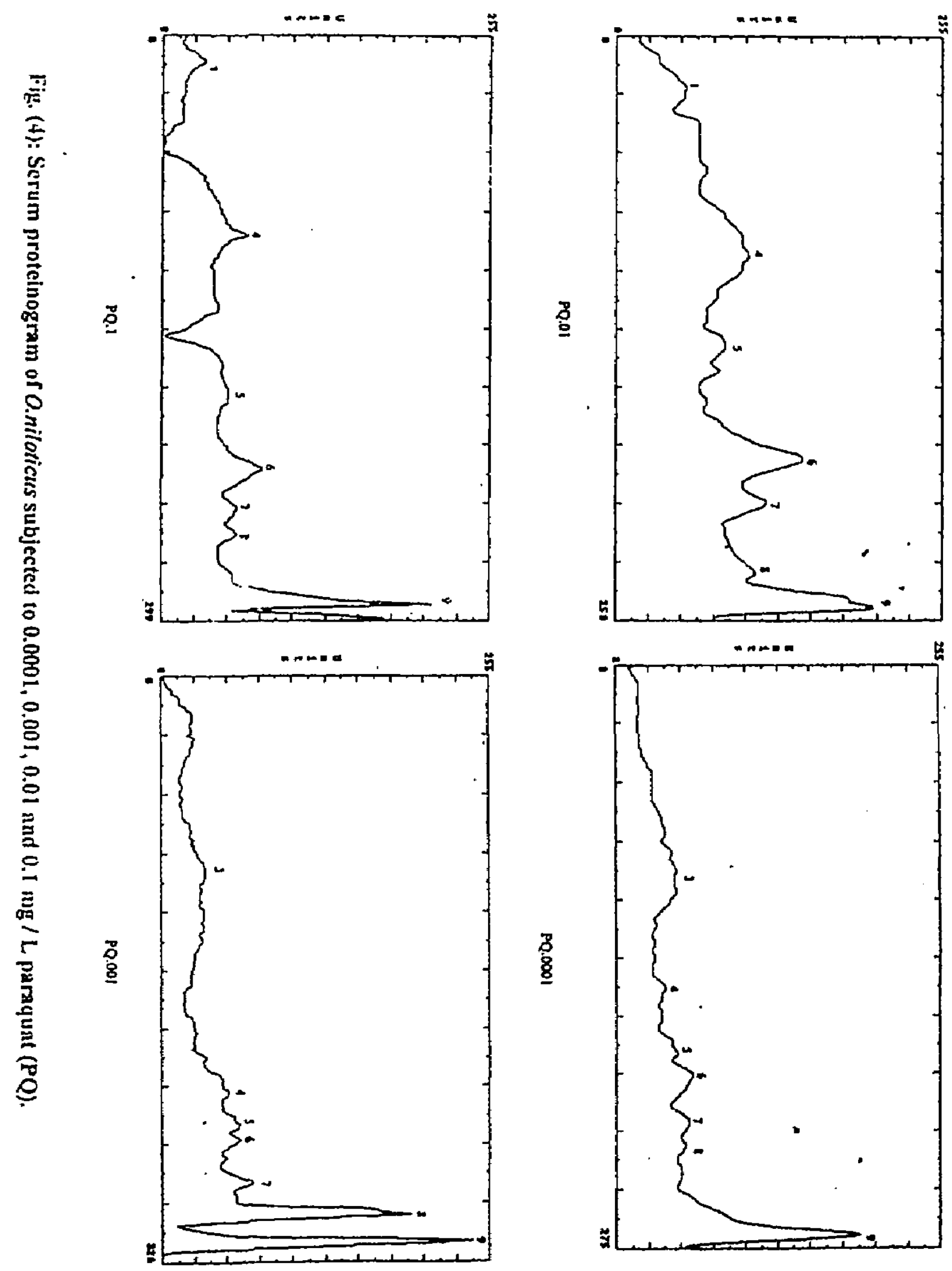